\title{
Performance of Weeder in Mechanically Transplanted Rice Cultivation
}

\author{
A K M S Islam, M A Hossen, M K A Bhuiyan, M M Islam and M A Rahman
}

\begin{abstract}
Field performance of low land weeder was evaluated in mechanically transplanted rice fieldat Bahirbagh and Provakordi representing the silty loam soil under Gopalganj district of Bangladesh during the non-irrigated wet season (Aman) 2016. Twenty-one-day-old seedlings were transplanted by walk behind type 4-rows mechanical rice transplanter (DP480) at a pre-set spacing of $300 \times 170 \mathrm{~mm}$. Randomized Complete Block (RCB) design with three replications was applied with weeding practices of BRRI weeder (BW) followed by (fb) one hand weeding (HW), BRRI power weeder (BPW) fb one HW, two HW, pyrazosulfuron-ethyl (PSE) fb one HW, weedy check, weed free and mulching fb two HW (farmers' practice) in two locations. The common weed species were observed in experimental sites. Weeding efficiency (WE) of BPW and BW was 67 and 44, respectively. Field capacity of BPW and BW was obtained 0.07 and $0.03 \mathrm{ha} \mathrm{hr}^{-1}$, respectively. Operator's skill influenced the performance of weeder. During operation, BPW damaged $14-15 \%$ tillers in both the locations. However, damaged plants were revived after few days. The labour requirement in BW fb one HW, BPW fb one HW, PSE fb one HW and two HW were 380, 362, 243 and 616 man-hr ha-1 respectively. Except weedy check, weed management practices showed identical grain yield in both the locations. The BCR was accounted in PSE fb one HW (1.35), BW fb one HW (1.21), BPW fb one HW (1.20) whereas the lowest BCR was observed in weedy $(0.83)$ and two HW (1.00). It can be concluded that pyrazosulfuron-ethyl, BRRI power weeder followed by one hand weeding and BRRI weeder followed by one hand weeding appeared as the cost effective weed control methods in mechanically transplanted Aman rice production.
\end{abstract}

Keywords: Transplanter, weeder, herbicide, labour, yield and benefit-cost ratio

\section{INTRODUCTION}

Rice is grown in about 11.35 million hectare of land in three distinct rice growing seasons are Boro (Dec-April), Aus (April-July) and Aman (Aug-Nov) (Hussain et al., 2012). The majority of rice area is covered by transplanted Aman rice comprising about 5.53 million hectare of the total rice area (BBS, 2015). Rice is predominantly grown by hand transplanting and required labour of 642-708 man-hr ha-1 of which seedlings raising and transplanting consumed $19-22 \%$ of the total labour requirement (Islam et al., 2016a). Hand transplanting of seedling is the most widely adopted and the most ancient method of rice transplanting. Rice transplanting method is changing from manual to mechanical transplanter due to unavailability of labour, burden to increase yield and save the crops from natural disaster. Mechanical transplanting improves labour efficiency, ensures timeliness in operation, faster transplanting and attains optimum plant density that contributes to high productivity (Islam et al., 2016a and Manjunatha et al., 2009). Weed is a serious problem in rice cultivation. Weed infestation is a natural and acute phenomenon in rice field. Weed depends on the availability of water supply, soil texture and structure, location of the field, weather and climatic condition of the field, depth of plough pan, and organic matter content of the soil (Hossen et al., 2015). 
Uncontrolled or improperly controlled weeds compete for soil nutrition with more rapidity in growth and population and cause substantial reduction in yield and grain quality. Severe weed infestation is one of the important factors for such a low yield. The prevailing climatic factors of Bangladesh are highly favourable for luxuriant growth of numerous species of weed, which offer a keen competition with rice crop (Alam et al., 1995). Without weed control, yield losses have been estimated 16 to $48 \%$ for transplanted Aman rice (Alam et al., 1996). Weed management requires huge labour resulting in increase of production cost. Lower weeding cost is always preferable from the economic point of view. Weed management is implemented in traditional way by manual labour or in mechanized way by mechanical weeder, power weeder or applying herbicide. Usually, two to three hand weedings are done for growing a transplant rice crop depending upon the nature of weeds and their intensity of infestation. Manual weeding requires 98 man-hr ha- ${ }^{1}$ labour input and there is a great scope of saving up to $78 \%$ cost in weeding operation by adopting mechanical means of weeding (Islam et al., 2016b). Mechanical rice transplanting is gaining popularity through the intervention of governmental and nongovernmental organizations in Bangladesh as it saved labour, ensured timely transplanting and optimum plant density that contributed to high productivity (Islam, 2016). Many prerequisite and requisite conditions for successful operation were not identified for Bangladesh condition. Seedling age and plant spacing is also different in mechanically transplanted field compared with the manually transplanted field. Weed management is thus an issue of reconsideration to suit with the mechanical interventions involved with the modern cultivation practices. Different weeding methods especially BRRI weeder and BRRI power weeder were evaluated in manually transplanted rice field. However, there is little understanding of their efficacy for mechanically transplanted rice. Therefore, a study was conducted to evaluate the performance of different low land weeder in mechanically transplanted rice in the farmers' field during the non-irrigated wet season.

\section{METHODOLOGY}

The experiment was conducted in the farmers' field at Bahirbagh and Provakordi under Muksudpur upazila, Gopalganj district of Bangladesh during wet season 2016 (Map 1). The soils of the experimental locations represented the silty loam soil. Experimental plots were designed considering the ease of rice transplanter (4-row walking type rice transplanter, model: DP 480) operation. Average sub-plot size of the experimental field was $238 \mathrm{~m}^{2}(17.0 \mathrm{~m}$ long and $14.0 \mathrm{~m}$ width) in Bahirbagh, whereas, it was $210 \mathrm{~m}^{2}$ $(20.0 \mathrm{~m}$ long and $10.5 \mathrm{~m}$ width) in Provakordi. Buffer spacing between treatments was $0.5 \mathrm{~m}$. The following seven weeding treatments were arranged in a randomized complete block (RCB) design with three replications. Each of the replication represented a block in the experiment. The treatments were $\mathrm{T}_{1}=\mathrm{BW} \mathrm{fb}$ one $\mathrm{HW}, \mathrm{T}_{2}=\mathrm{BPW}$ fb one HW, $\mathrm{T}_{3}=$ Two $\mathrm{HW}, \mathrm{T}_{4}=$ Pyrazosulfuron-ethyl (PSE) fb one HW, $\mathrm{T}_{5}=$ Weedy check, $\mathrm{T}_{6}=$ Weed free and $\mathrm{T}_{7}$ $=$ Mulching fb two HW (Farmers' practice).

High yielding inbred rice variety BRRI dhan39 was transplanted as variety in Aman season. Twenty-one-day-old seedlings were transplanted in the experimental plots on 19 July 2016 in Bahirbagh and 17 August 2016 in Provakordi respectively. A rotary tiller powered by 2-WT was used for land preparation. Three rotary tillage passes in saturated soil, followed by one leveling, were the operations for land preparation. Plastic tray $(580 \times 280 \times 25 \mathrm{~mm})$ was used for raising 
mat type seedlings. Clod-free sandy loam soil collected from the respective field was used to fill-up the trays. A total of $130 \mathrm{~g}$ of pregerminated seeds were spread uniformly on each tray. When the radicals and coleoptiles elongate to $1 / 3$ of seed length is desired for pre-germinated seed to broadcast. After sowing, fine and loose soil was spread over the seeds to 3-5 $\mathrm{mm}$ depth. Sprinkling water was applied twice a day until complete emergence of seedlings. Seedlings of 125 to $150 \mathrm{~mm}$ height with 2-3 leaves were used in the experiment of Bahirbagh and Provakordi respectively. Walk behind 4-rows mechanical rice transplanter (model- DP480) was operated at a pre-set spacing of $300 \times 170 \mathrm{~mm}$. There are three options in the rice transplanter (DP 480) to adjust the hill spacing (plant-to-plant spacing). The transplanter was set to maintain $170 \mathrm{~mm}$ distance between hills spacing in the row. Spacing between rows (line to line spacing) was fixed to $300 \mathrm{~mm}$ for the rice transplanter. The transplanting depth control lever was adjusted to the medium mode during field operation to maintain $20-30 \mathrm{~mm}$ depth of seedlings placement. Number of seedlings hill $^{-1}$ were adjusted based on the seedling density setting. There were nine options to select number of seedlings hill-1. The picker was set at point 4 to maintain similar numbers of seedlings hill- ${ }^{-1}$ in all treatments for both the locations. During transplanting, minimum standing water was maintained in the field to reduce the floating hills as well as missing hills. Bunds around the individual plots were repaired as and when necessary to control the water flow between the plots. Hill to hill distance of the transplanted seedlings was measured randomly in three places of each sub-plot from $1.0 \mathrm{~m}$ of length. Number of plants hill-1 was collected after transplanting from $0.25 \mathrm{~m}^{2}$ of area of each sub plots.

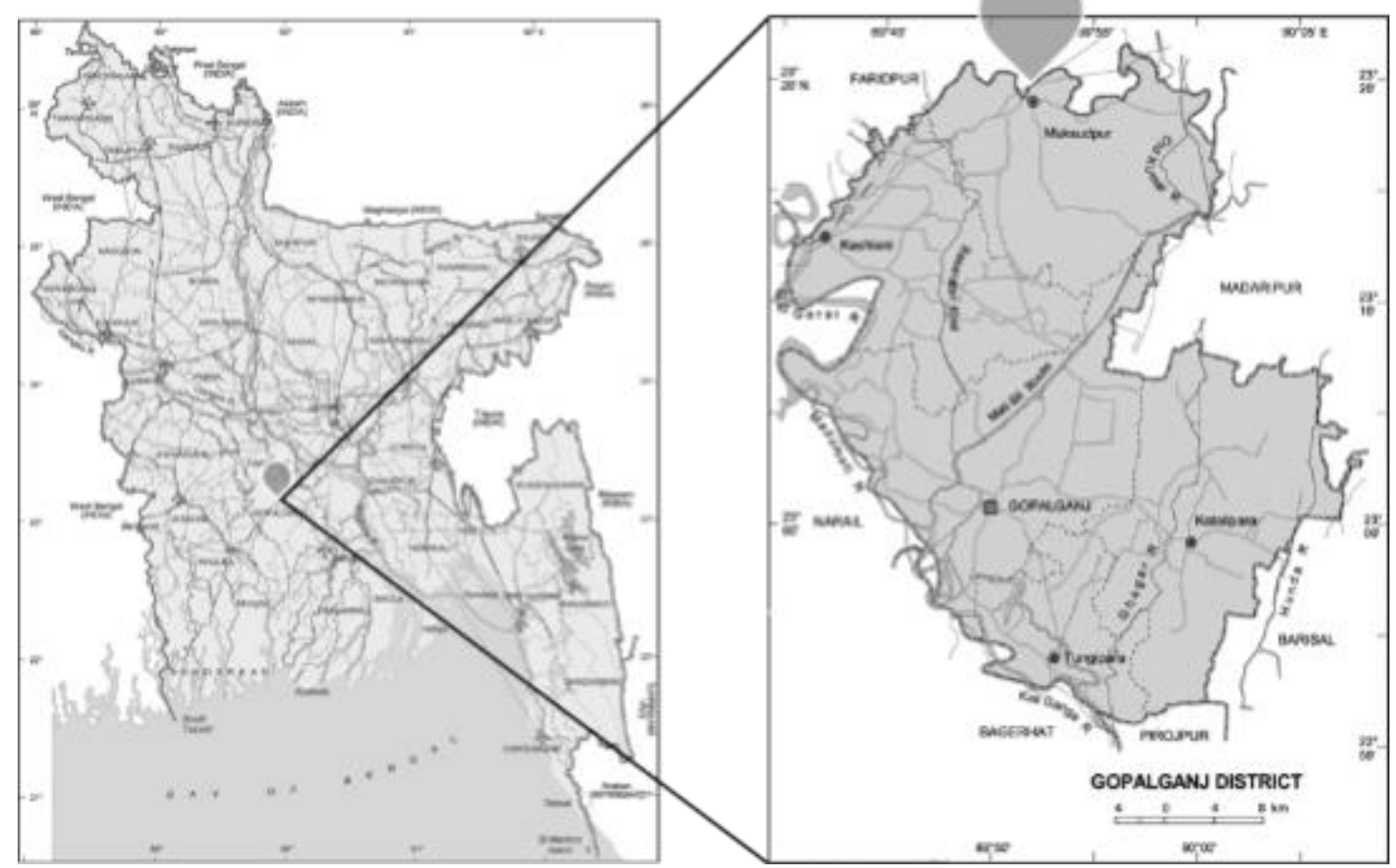

Map 1. Location of the experimental site. 


\section{Weed management}

Weeds were managed according to the design and treatments. BW and BPW were operated at 25 DAT (Days after transplanting) in both the locations. Pyrazosulfuron-ethyl was applied to control weeds in $\mathrm{T}_{4}$ at 7 DAT at the rate of $150 \mathrm{~g} \mathrm{ha}^{-1}$. One hand weeding was done at 45 DAT to control the weeds of $T_{1}, T_{2}, T_{3}$ and $\mathrm{T}_{4}$ plots. Whereas, $\mathrm{T}_{6}$ (weed free) was weeded at 22, 30, 40 and 50 DAT to keep the field weed free throughout the crop growing period. In case of $T_{7}$, weeds were controlled by the farmers manually at 15, 25 and 40 DAT.

\section{Weeding efficiency}

Weeding efficiencies (WE) of the BRRI weeder and BRRI power weeder were measured by counting the number of weeds of the preselected area before and after weeding. At each sampling time, three quadrates of $0.5 \mathrm{~m} \times$ $0.5 \mathrm{~m}$ were placed randomly in each sub-plot and weeds were collected from each quadrate before and after weeding. Weeding efficiency was calculated using the following equation (Remesan et al., 2007).

$\mathrm{WE}=\frac{\mathrm{W}_{1}-\mathrm{W}_{2}}{\mathrm{~W}_{1}} \times 100$

where,

WE $=$ Weeding efficiency, $\%$

$\mathrm{W}_{1}=$ Weed population before weeding, no.

$W_{2}=$ Weed population after weeding, no.

\section{Tiller damage}

It is the measure of damage on crop plants while weeding operation done and it depends on the uniformity of plant to plant spacing, skill of the operator, field condition and standing water of the experimental fields. Minimum standing water (around $10 \mathrm{~mm}$ ) was maintained during weeding. In order to determine the damaged plant, bamboo frame of $0.50 \times 0.50 \mathrm{~m}$ was thrown in the field randomly in three places of each plot and the number of damaged plants in the frame was counted (Tewari et al., 1993). Number of tiller damage during weeding practices was calculated by the following equation:

$\operatorname{DTR}=\frac{\mathrm{Q}_{2}}{\mathrm{Q}_{1}} \times 100$

where,

DTR $=$ Damaged tiller ratio, $\%$

$\mathrm{Q}_{1}=$ Plants in $1 \mathrm{~m}^{2}$ area before weeding, no.

$\mathrm{Q}_{2}=$ Damaged plants in $1 \mathrm{~m}^{2}$ area after weeding, no.

The recommended fertilizer doses for Aman season (cv. BRRI dhan39) were applied at the same rate for all treatments (BRRI, 2013). Diammonium phosphate (DAP), muriate of potash (MoP), zinc sulphate $\left(\mathrm{ZnSO}_{4}\right)$ and gypsum fertilizers were applied in the soil before transplanting as basal. Urea (N) was broadcast in three equal splits at seven days after transplanting, vegetative stage and before panicle initiation. Pest attacked the plants severely during the study period. However, pests were controlled by two applications of Furadan 5G and Theovit 80 WG along with Virtako 40 WG pesticide to control yellow stem borer and other insect infestation at 28 and 48 DAT in both the locations. Pesticide was mixed with 500-600 liter of water to spray in one hectare of land. Experimental plots were irrigated as and when needed.

\section{General performance parameters}

The performance parameters of the low land weeders are common (i.e. forward speed, theoretical and actual field capacity, effective operating time, field efficiency and fuel consumption) as discussed sequentially (Hunt, 1995). All these parameters were used to calculate cost of production and benefit-cost ratio of rice production under different weeding practices.

The time required by a machine to travel certain distance in the field was recorded and then machine forward speed was calculated using the following equation: 
$S=\frac{D}{t} \times 3.6$

where,

$\mathrm{S}=$ Machine forward speed, $\mathrm{km} \mathrm{hr}^{-1}$

$\mathrm{D}=$ Distance, $\mathrm{m}$

$t=$ Time required to cover the distance $D$, sec

Theoretical field capacity was calculated as a function of speed and operating width by the following equation:

$\mathrm{C}_{0}=\frac{\mathrm{W} \times \mathrm{S}}{\mathrm{C}}$

where,

$\mathrm{C}_{0}=$ Theoretical field capacity, ha hr-1

$\mathrm{W}=$ Operating width of the machine, $\mathrm{m}$

$\mathrm{C}=$ Constant, 10

Actual field capacity was calculated as a function of total area and total field time by the following equation :

$\mathrm{Ca}=\frac{\mathrm{A}}{\mathrm{T}}$

where,

$\mathrm{Ca}=$ Actual field capacity, ha hr-1

$\mathrm{A}=$ Total area covered, ha

$\mathrm{T}=$ Total operating time required for transplanting, hr

The effective operating time of the machine, as a function of time required by it to cover a unit of area performing its task successfully, was measured by the following equation;

$\mathrm{E}_{\mathrm{T}}=\frac{1}{\mathrm{Ca}}$

where,

$\mathrm{E}_{\mathrm{T}}=$ Effective operating time, $\mathrm{hr}$ ha-1

The field efficiency, as a function of theoretical and actual field capacity was calculated by the following equation :

$\mathrm{Ef}=\frac{\mathrm{Ca}}{\mathrm{C}_{0}} \times 100$

where,

Ef $=$ Field efficiency, \%
The fuel consumption was measured from the amount of refill after finishing an operation and was calculated by using the following equation:

$\mathrm{F}=\frac{\mathrm{Ft}}{\mathrm{T}}$

where,

$\mathrm{F}=$ Fuel consumption rate, $1 \mathrm{hr}^{-1}$

$\mathrm{Ft}=$ Total fuel used during operation, 1

$\mathrm{T}=$ Total time needed for operation, $\mathrm{hr}$

\section{Operating cost of weeder}

Operating cost of weeder was calculated considering the fixed cost and variable cost using the method mentioned in Hunt (1995). Depreciation, interest on investment, tax, insurance and shelter are the components of fixed cost and calculated using the following equations:

Depreciation, $\mathrm{D}=\frac{\mathrm{P}-\mathrm{S}}{\mathrm{L}}$

Interest on investment, $\mathrm{I}=\frac{\mathrm{P}+\mathrm{S}}{2} x i$

where,

$\mathrm{D}=$ Depreciation, $\mathrm{Tk}_{\mathrm{yr}} \mathrm{r}^{-1}$

$\mathrm{P}=$ Purchase price of the weeder, Tk

$\mathrm{S}=$ Salvage value, $\mathrm{Tk}$

$\mathrm{L}=$ Working life of the weeder, $\mathrm{yr}$

$\mathrm{i}=$ rate of interest

Fixed cost, FC $\left(\mathrm{Tk} \mathrm{yr}^{-1}\right)=$ Depreciation + Interest on Investment $+\operatorname{Tax}(3 \%$ of purchase price) + insurance and shelter cost.

In variable cost calculation, the cost of fuel, lubrication, daily service, power and labour were considered. These costs increase with the increase of machine use and vary to a large extent in direct proportion to days of use per year.

Variable cost, VC $\left(\mathrm{Tk} \mathrm{hr}^{-1}\right)=$ Labour cost + Fuel cost + Oil cost $(3 \%$ of fuel cost) + Repair and maintenance cost (3.5\% of purchase price).

Yield and yield contributing character

Excess water was drained out from the plots before 15 days of harvest to enhance maturity 
of the crop. Crops were harvested on 2 November 2016 in Bahirbagh and 27 November 2016 in Provakordi respectively. Rice grain yield was recorded from a preselected $10 \mathrm{~m}^{2}$ harvest area and was determined with the adjustment to $14 \%$ moisture content.

\section{Cost estimation}

Cost of rice production under different weeding practices was calculated based on total production cost. Rental charge of the land and input costs were the components of production cost. Seedling raising, land preparation, fertilizer, labour, herbicides, weeding, transplanter, intercultural operation, irrigation, harvest and post-harvest costs were the components of input cost. Market price of the crop was collected from local markets. Price of the product and production costs were used to calculate gross return, gross margin and benefit-cost ratio. The benefit-cost ratio (BCR) was computed as the gross return divided by production cost. Gross margin was also calculated by subtracting the total inputs from gross return.

\section{Statistical analysis}

Data were analyzed as a single factorial design according to Gomez and Gomez (1984) using Statistix 10 programme (Statistix 10 software, 2013). Means were compared with the least significant difference (LSD) test.

\section{RESULTS AND DISCUSSION}

\section{Plant spacing and seedling dispensed per stroke}

The ultimate productivity of a crop is determined by plant population (Baloch et al., 2007). Before operation of the transplanter, plant to plant spacing was set at $17 \mathrm{~cm}$, and seedling density was set at 4 . In actual field condition, plant to plant spacing was obtained 17.1 and $17.4 \mathrm{~cm}$ in Bahirbagh and
Provakordi respectively (Fig. 1). Islam et al. (2017) mentioned that the variation was caused by the slippage and skidding of the transplanter.

\section{Weed species}

There are nine common weed species were observed in the experimental sites. The weed species in the experimental plots were Cyperus rotundus, Cynodon dactylon, Digitaria ischaemum, Eleusine indica, Alternanthera philoxeroides, Monochoria vaginalies, Cyperus difformis, Nicotiana plumbaginifolia and Ranunculus scleratus.

\section{Weeding efficiency}

Weeding efficiency (WE) of weeder was depended on the severity of weed, soil moisture and weeding regime. WE of $\mathrm{BPW}$ and BW was obtained 66 and 44\%, respectively (Fig. 2). The WE of BW was lower than BPW because BW eliminated weeds within $20 \mathrm{~cm}$ of spacing as the width of BW was $20 \mathrm{~cm}$ and $10 \mathrm{~cm}$ space remained unweeded in mechanically transplanted rice field. BW having the width of $20 \mathrm{~cm}$ is not suitable for mechanically transplanted rice. Therefore, the width of BW should be increased to get the better WE. On the other hand, BPW exerted the sufficient power in rotor and caused better blades grips with soil, resulting in higher WE of the weeder. Islam et al. (2016b) and Islam et al. (2017) tested the WE of BW and BPW in two types of soil in wet season rice cultivation and found the WE of BPW was higher than BW. Alizadeh (2011) tested the WE of two types of weeder in low land rice cultivation in Iran and found that WE of power weeder (84\%) was higher than the rotary weeder (73\%). Ramesan et al. (2007) observed that the WE of rotary weeder was $72 \%$. Subudhi (2004) reported that the WE of different types of hand operated weeder was 76 to $91 \%$. Islam et al. (2017) reported that the WE of BPW and BW was $78 \%$ and $73 \%$ in hand transplanted plot. These findings are not 
consistent to the results of the present experiment due to weeder was operated in sandy loam soil and weed infestation was severe. Generally, WE depended on the weeder type, weed species, weeding time and soil condition. If weeding is delayed, the WE will be decreased for excessive growth of weeds in soil and improper involvement of machine blades in soil depth.
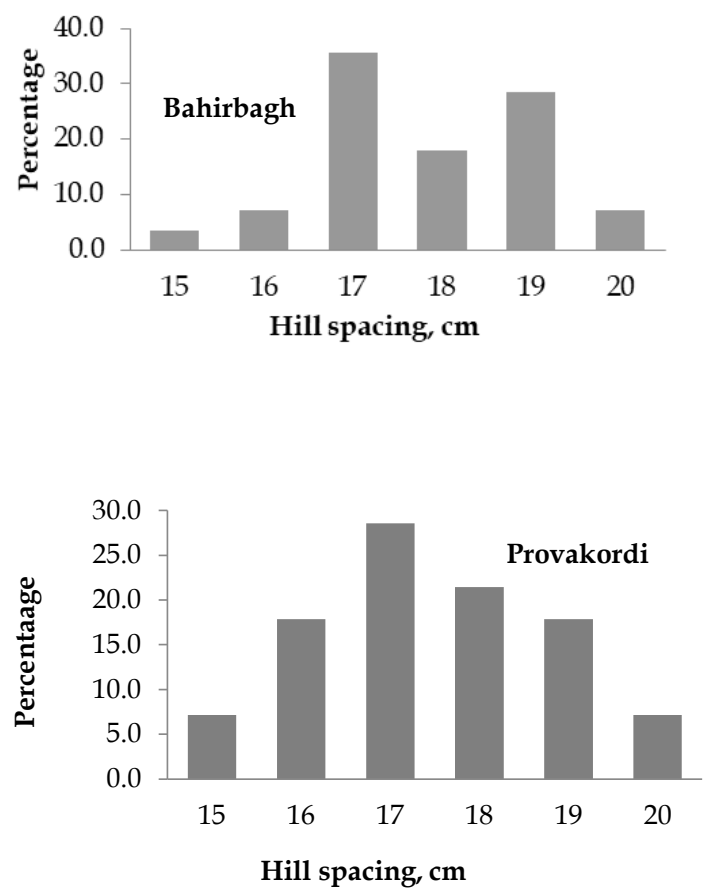

Fig. 1. Plant spacing at Bahirbagh and Provakordi.

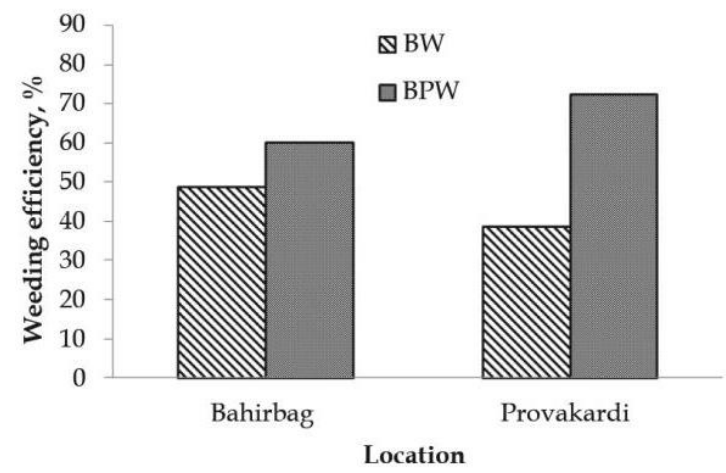

Fig. 2. Weeding efficiency of two types of weeder.

\section{Field capacity}

Field capacity is an important factor for any kind of machine operation. Field capacity of BPW and BW was obtained 0.07 and 0.03 ha $\mathrm{hr}^{-1}$ respectively (Fig. 3). Islam et al. (2016b and 2017) studied the field capacity of BW and BPW in other soil types and obtained almost similar results due to variation of soil types. Operator's skill influenced the weeder performance. At the end of each pass, operator lifted the machine, placing it in another new rows and started operation. This increased the turning time loss, which reduced the field capacity of the BPW.

\section{Tiller damage}

Plant spacing is an important factor for successful weeding operation. Results indicated that $14-15 \%$ plants were damaged during operation of the BPW in Bahirbagh and Provakordi respectively (Fig. 4). The damaged plants were revived after few days. Similar results were obtained by Islam et al. (2016b and 2017). The movement of weeder machines encountered difficulties in BPW because of the distribution pattern and shading of plant over spaces between the rows.

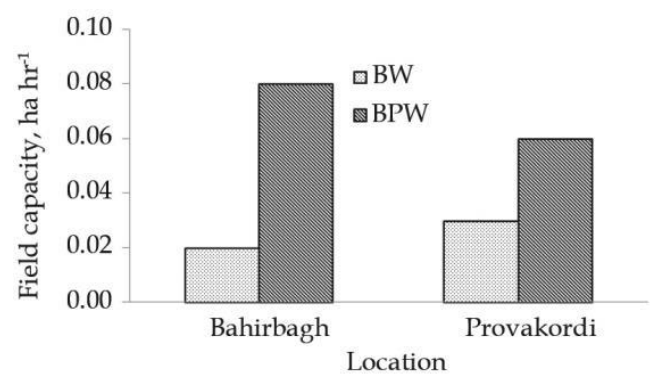

Fig. 3. Field capacity of BW and BPW.

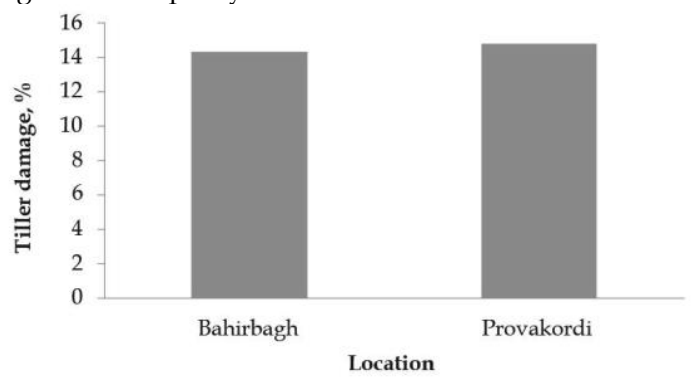

Fig. 4. Tiller damage by BPW. 


\section{Labour requirement and weeding cost}

Labour requirement and cost of weeding in rice production is one of the major input cost. Both the labour requirement and cost for weeding were varied significantly with the weeding practices (Table 1). In Bahirbagh, the highest number of labourer was required for mulching fb two HW, which was similar to two HW whereas the lowest number of labourer was required in PSE fb one HW, which was similar to BPW. Weeding cost is linearly proportional with the labour requirements for different weed management practices. In Provakordi, significantly higher labour was required in making the rice field weed free, which was similar to mulching fb two HW whereas the lowest and similar labour was required for the rest of the weed management practices. On average, $\mathrm{BW} \mathrm{fb}$ one $\mathrm{HW}, \mathrm{BPW} \mathrm{fb}$ one HW and PSE fb one HW reduced 38, 41 and $61 \%$ labour compared to hand weeding. Islam et al. (2016a) stated that BRRI weeder, BRRI power weeder and herbicide application reduced 74, 91 and $98 \%$ labour and 72, 63 and $82 \%$ cost compared to hand weeding. Alizadeh (2011) mentioned that the labour input in mechanical weeder was obtained 36 man-hr ha-1 whereas 112 man- $\mathrm{hr} \mathrm{ha}^{-1}$ in hand weeding. These values were lower than the present finding. This might be due to the variation in weed density, type of weed and weeding regime.

\section{Yield and yield contributing characters}

Weed management practices showed significant effect on grain yield in Bahirbagh. Weedy check gave significantly lower yield followed by mulching fb two HW while yield of paddy in other weeding practices gave statistically similar yield (Table 2). In Provakordi, except weedy check, all other treatments produced statistically similar yield. Averaged over two locations, PSE fb one HW gave higher yield followed by BPW fb one $\mathrm{HW}, \mathrm{BW} \mathrm{fb}$ one HW and weed free.

\section{Economic analysis}

Economic analysis included cost of production and return from paddy and straw (Table 3). PSE fb one HW (1.35), BW fb one HW (1.21) and BPW fb one HW (1.21) accounted for the highest BCR while weedy check (0.94) and two HW (1.06) gave the lowest BCR in Bahirbagh. Similar pattern of BCR was observed in Provakordi.

Table 1. Labour requirement as affected by weed management practices.

\begin{tabular}{|c|c|c|c|c|c|c|}
\hline \multirow[t]{2}{*}{ Weeding method } & \multicolumn{3}{|c|}{ Labour (man-hr ha-1) } & \multicolumn{3}{|c|}{ Cost $($ TK ha-1) } \\
\hline & Bahirbagh & Provakordi & Average & Bahirbagh & Provakordi & Average \\
\hline BW fb one HW & 538 & 222 & 380 & 20436 & 9667 & 15052 \\
\hline $\mathrm{BPW}$ fb one HW & 402 & 322 & 362 & 16519 & 15406 & 15963 \\
\hline Two HW & 897 & 335 & 616 & 33622 & 14676 & 24149 \\
\hline PSE fb one HW & 278 & 207 & 243 & 10413 & 9046 & 9730 \\
\hline Weedy check & 0 & 0 & 0 & 0 & 0 & 0 \\
\hline Weed free & 737 & 580 & 659 & 23042 & 25358 & 24200 \\
\hline Mulching fb two HW & 1074 & 345 & 710 & 40260 & 15079 & 27670 \\
\hline Mean & 561 & 287 & 380 & 20613 & 12747 & 16680 \\
\hline $\mathrm{LSD}_{0.05}$ & 194.14 & 242.43 & - & 7368.2 & 10732 & - \\
\hline $\mathrm{CV}, \%$ & 19.46 & 47.43 & - & 20.09 & 47.32 & - \\
\hline
\end{tabular}

Note: BW=BRRI weeder, BPW= BRRI power weeder, PSE = Pyrazosulfuron-ethyl, fb=followed by, HW=hand weeding, NS=Not significant 
Table 2. Grain yield $\left(t^{~ h a-1}\right)$ as affected by weed management practices.

\begin{tabular}{|c|c|c|c|}
\hline \multirow[t]{2}{*}{ Weeding methods } & \multicolumn{2}{|c|}{ Location } & \multirow[t]{2}{*}{ Mean } \\
\hline & Bahirbagh & Provakordi & \\
\hline BW fb one HW & 5.7 & 4.7 & 5.2 \\
\hline BPW fb one HW & 5.5 & 5.0 & 5.3 \\
\hline Two HW & 5.4 & 4.7 & 5.0 \\
\hline PSEfb one HW & 5.7 & 5.2 & 5.4 \\
\hline Weedy check & 3.0 & 3.6 & 3.3 \\
\hline Weed free & 5.6 & 4.8 & 5.2 \\
\hline One mulching fb two HW & 4.6 & 5.2 & 4.9 \\
\hline Mean & 5.1 & 4.7 & 4.9 \\
\hline $\mathrm{LSD}_{0.05}$ & 0.75 & 0.50 & - \\
\hline $\mathrm{CV}, \%$ & 12.55 & 9.01 & - \\
\hline
\end{tabular}

Note: $\mathrm{BW}=\mathrm{BRRI}$ weeder, $\mathrm{BPW}=\mathrm{BRRI}$ power weeder, $\mathrm{PSE}=$ Pyrazosulfuron-ethyl, fb=followed by, $\mathrm{HW}=$ hand weeding, NS=Not significant

Table 3. Benefit-cost ratio as affected by weed management practices in mechanically transplanted rice.

\begin{tabular}{|c|c|c|c|c|c|c|c|c|c|}
\hline \multirow[t]{2}{*}{ Weeding method } & \multicolumn{2}{|c|}{$\begin{array}{l}\text { Input cost } \\
\left(\text { Tk ha }^{-1}\right)\end{array}$} & \multicolumn{2}{|c|}{$\begin{array}{l}\text { Gross return } \\
\left(\text { Tk ha }^{-1}\right)\end{array}$} & \multicolumn{2}{|c|}{$\begin{array}{c}\text { Gross margin } \\
\left(\mathrm{Tk} \mathrm{ha}^{-1}\right)\end{array}$} & \multicolumn{2}{|c|}{ BCR } & \multirow[t]{2}{*}{ Mean } \\
\hline & L1 & L2 & L1 & L2 & L1 & L2 & L1 & $\mathrm{L} 2$ & \\
\hline $\mathrm{BW}$ fb one HW & 97,985 & 85,427 & 120,840 & 101,050 & 22,855 & 15,623 & 1.23 & 1.18 & 1.21 \\
\hline $\mathrm{BPW} \mathrm{fb}$ one $\mathrm{HW}$ & 94,765 & 91,854 & 116,600 & 107,500 & 21,835 & 15,646 & 1.23 & 1.17 & 1.20 \\
\hline Two HW & 113,920 & 91,037 & 114,480 & 101,050 & 560 & 10,013 & 1.00 & 1.11 & 1.06 \\
\hline PSEfb one HW & 87,925 & 84,732 & 120,840 & 111,800 & 32,915 & 27,068 & 1.37 & 1.32 & 1.35 \\
\hline Weedy check & 76,263 & 74,600 & 63,600 & 77,400 & $-12,663$ & 2,800 & 0.83 & 1.04 & 0.94 \\
\hline Weed free & 102,070 & 103,001 & 118,720 & 103,200 & 16,650 & 199 & 1.16 & 1.00 & 1.08 \\
\hline One mulching fb two HW & 93,908 & 91,488 & 97,520 & 111,800 & 3,612 & 20,312 & 1.04 & 1.22 & 1.13 \\
\hline
\end{tabular}

Note. L1 = Bahirbagh, L2 = Provakordi, BW=BRRI weeder, BPW= BRRI power weeder, PSE = Pyrazosulfuron-ethyl, $\mathrm{fb}=$ followed by, $\mathrm{HW}=$ hand weeding, $\mathrm{NS}=$ Not significant

Petrol: Tk 90 L-1, Labour (normal) Tk 300 day-1, Labour (skilled): Tk 400 day-1, Paddy:Tk 20 kg-1, Straw: Tk 1.88 kg-1.

\section{CONCLUSION}

Considering weeding efficiency and cost as well as benefit-cost ratio pyrazosulfuron-ethyl, BRRI power weeder and BRRI weeder followed by one hand weeding were found more suitable in mechanically transplanted rice field.

\section{RECOMMENDATIONS}

The width of BRRI weeder should be modified for operating in the wider spaced mechanically transplanted rice field.

\section{REFERENCES}

Alam, M S, B K Biswas, M A Gaffer and M K Hossain. 1995. Weed control in upland rice. Efficiency of weeding at different stages of seedlings emergence in direct-seeded Aus rice. Bangladesh J. Sci. Ind. Res., 30: 155-167.

Alam, M S, M N Islam, A K M Zaman, B K Biswas and M K Saha. 1996. Relative efficiency and economics of different cultural methods and herbicides for weed control in transplanted Aus rice. Bangladesh J. Agric. Sci., 23: 67-73.

Alizadeh, M R. 2011. Field performance evaluation of mechanical weeders in the paddy field. Scientific Research and Essays, 6 (25): 5427-5434.

Baloch, M S, I U Awan, GHassanand M Z Ubair. 2007. Studies on Plant Population and Stand Establishment Techniques for Increasing Productivity of Rice in Dera Ismail Khan, Pakistan, Rice Science, 14 (2): 118-124.

BBS. 2015. Labour for survey Bangladesh 2013. Bangladesh Bureau of Statistics. Dhaka, Bangladesh.

Gomez, KA and A A Gomez. 1984. Statistical Procedures in Agricultural Research, New York, Chichester, etc.: Wiley, 2nd edition, pp. 680.

Hossen, M A, M A Alam, S Paul and M A Hossain. 2015. Modification and evaluation of a power weeder for Bangladesh condition. Eco-friendly Agril. J. 8 (03): 37-46. 
Hunt, D. 1995. Farm Power and Machinery Management, Cost determination, $9^{\text {th }}$ edition, Iowa State University press, USA.

Hussain, S G, M K A Chowdhury and M A H Chowdhury. 2012. Land suitability assessment and crop zoning map. Bangladesh Agricultural Research Council, Dhaka, Bangladesh.

Islam, A K M S. 2016. Mechanized Rice Transplanting in Bangladesh. Publication number 218. Bangladesh Rice Research Institute, Gazipur.

Islam, A K M S, M A Rahman, A K M L Rahman, M T Islam and M I Rahman. 2016a. Technoeconomic performance of 4-row self-propelled mechanical rice transplanter at farmers' field in Bangladesh. Progressive Agriculture 27 (3): 369382.

Islam, A K M S, M T Islam, M S Rahman, M A Rahman and Y Kim. 2016b. Investigation on selective mechanization for wet season rice cultivation in Bangladesh. Journal of Biosystems Engineering, 41 (4): 294- 303.
Islam, A K M S, M T Islam, M Sh Islam, A K M L Rahman, MA Rahman and M I Rahman. 2017. Performance evaluation of BRRI mechanical and power weeder in low land rice cultivation. Paper accepted for The Agriculturist Journal.

Manjunatha, M V, B G M Reddy, S D Shashidhar and V R Joshi. 2009. Field performance evaluation of vertical conveyor paddy reaper. Karnataka J. Agric. Sci., 22 (1): 140-142.

Remesan, R, M S Roopesh, N Remya and P S Preman. 2007. Wet land weeding- A comprehensive comparative study from south India. The CIGR E-journal. Manuscript PM 07011, 9:1-21.

Subudhi, C R. 2004. Evaluation of weeding devices for upland rice in the eastern Ghat of Orissa, India. International Rice Research Notes (IRRN), 29 (1): 79- 80.

Tewari, V K, R K Datta and A S Murthy. 1993. Field performance of weeding blades of a manually operated push-pull weeder. Journal of Agriculture Engineering Research, 55 (2): 129-141. 